\title{
BEHAVIOR AND BONDING CHARACTERISTICS OF SELF-COMPACTING CONCRETE
}

\author{
Ashraf M. Heniegal, Walid S. Elsayed \\ Civil structures dept., faculty of industrial education, Suez Canal univ., \\ Suez, Egypt
}

(Received November 16, 2006 Accepted January 13, 2007)

Self-compacting concrete, also referred to as self-consolidating concrete, is able to flow and consolidate under its own weight and is deaerated almost completely while flowing in the formwork. It is cohesive enough to fill the spaces of almost any size and shape without segregation or bleeding. This makes SCC particularly useful wherever placing is difficult, such as in heavily-reinforced concrete members or in complicated formworks. Considering the economy and the durability of our present concrete structures, the quality and the density of the concrete cover, as well as the compaction of the concrete are main parameters [1]. The objectives of this research were to compare the Splitting Tensile Strength and Compressive Strength values of self-compacting and normal concrete specimens and to examine the bonding between the coarse aggregate and the cement paste using the Scanning Electron Microscope. Cylinder specimens ( $8^{\prime \prime}$ by $\left.4^{\prime \prime}\right)$ were tested for Splitting Tensile and Compressive Strength after 28 days of standard curing, in order to find out if self-compacting concrete would show an increase in these strengths and a better bonding between aggregate and cement paste, compared to normal concrete. The mix design used for making the concrete specimens was based on previous research works from literature. The water cement ratios varied from 0.3 to 0.6 while the rest of the components were kept the same, except the chemical admixtures, which were adjusted for obtaining the self-compactability of the concrete.

All SCC mixtures exhibited greater values in both splitting tensile and compressive strength after being tested, compared to normal concrete. The splitting tensile strength increased by approximately 30\%, whilst the compressive strength was around $60 \%$ greater. In addition, the SCC tensile strengths after 7 days were almost as high as those obtained after 28 days for normal concrete. This was possible due to the use of mineral and chemical admixtures, which usually improve the bonding between aggregate and cement paste, thus increasing the strength of concrete. Images taken from concrete samples having water-cement ratios of 0.3 , 0.4, and 0.6, using the Scanning Electron Microscope, have shown that the widths of the physical interface micro cracks were greater for normal 
concrete than for self-compacting concrete, which implies that the aggregate-cement bonds were better for SCC than for normal concrete.

KEYWORDS: self-compacting concrete, splitting tensile, compressive strength, physical interface.

\section{INTRODUCTION}

Development of self-compacting concrete (SCC) is a desirable achievement in the construction industry in order to overcome problems associated with cast-in-place concrete. Self compacting concrete is not affected by the skills of workers, the shape and amount of reinforcing bars or the arrangement of a structure and, due to its highfluidity and resistance to segregation it can be pumped longer distances [2]. The concept of self compacting concrete was proposed in 1986 by professor Hajime Okamura [3], but the prototype was first developed in 1988 in Japan, by professor Ozawa [4] at the University of Tokyo. The concept of self-compacting concrete was proposed in 1986 by professor Hajime Okamura and Maekawa [5,6]. Self-compacting concrete was developed at that time to improve the durability of concrete structures. The introduction of "modern" self-leveling concrete or self-compacting concrete (SCC) is associated with the drive towards better quality concrete pursued in Japan around 1983, where the lack of uniform and complete compaction had been identified as the primary factor responsible for poor performance of concrete structures (Dehn et al., 2000)[7].

Investigations for establishing a rational mix-design method and self-compactability testing methods have been carried out from the viewpoint of making it a standard concrete. Self-compacting concrete is cast so that no additional inner or outer vibration is necessary for the compaction. It flows like "honey" and has a very smooth surface level after placing. With regard to its composition, self-compacting concrete consists of the same components as conventionally vibrated concrete, which are cement, aggregates, and water, with the addition of chemical and mineral admixtures in different. Usually, the chemical admixtures used are high-range water reducers (super plasticizers) and viscosity-modifying agents, which change the theological properties of concrete. Mineral admixtures are used as an extra fine material, besides cement, and in some cases, they replace cement. In this study, the cement content was partially replaced with mineral admixtures, e.g. fly ash, slag cement, and silica fume, admixtures that improve the flowing and strengthening characteristics of the concrete. The main objectives set for this research were to compare the Splitting Tensile Strength and Compressive Strength of self-compacting and normal concrete specimens and to examine the bonding between the coarse aggregate and the cement paste for both types of concrete, using Scanning Electron Microscope. The criteria used were based on 28-day compressive and splitting tensile strength of conventional and selfcompacting concrete for five water-cement ratios. Also, 7-day tests were carried out for both types of concrete using only one water-cement ratio (0.4). Examination of aggregate-cement bonding has been undertaken in order to find out if a better bonding exists in self-compacting concrete, compared to normal concrete, due to the use of chemical and mineral admixtures in the former. This was carried out by observing the 
physical interface, represented by the contact zone between the aggregate particles and the cement paste surrounding them. The immediately adjacent zone is called interfacial transition zone (ITZ), in which the structure of the cement paste is quite different from that of the "bulk" paste. This zone, which has a typical 20-50 $\mu \mathrm{m}$ thickness, plays a very important role in the stiffness, strength, and permeability of cementitious materials containing aggregate due to its generally lower density and decreased strength compared to that provided by bulk cement paste. It also affects significantly the physical interface (increases it) due to the accumulations of calcium hydroxide and ettringite around the aggregate. For attaining high strengths, especially in tension, a significant reduction of the interfacial transition zone is desired, because this practically limits the strength of the aggregate-cement paste bond.

\section{EXPERIMENTAL PROCEDURES}

Conventional concrete tends to have a difficulty regarding the adequate placing and consolidation in thin sections or areas of congested reinforcement, which leads to a large volume of entrapped air voids and compromises the strength and durability of the concrete. Using self compacting concrete (SCC) can eliminate the problem, since it was designed to consolidate under its own weight. Therefore, it is important to verify the mechanical properties of SCC before using it for practical applications.

The experimental program was divided into two phases. In the first phase eleven sets of cylindrical specimens were made, each containing six cylinders, in order to be tested for compressive and splitting tensile strength after 28 days of standard curing. The water-cement ratios were $0.3,0.4,0.45,0.5$, and 0.6 . Three normal and three selfcompacting concrete specimens were tested for compressive and splitting tensile strength, for each of the five water-cement ratios. In addition, another three normal concrete and three self-compacting concrete specimens were made, with the watercement ratio of 0.4 , in order to be tested only for splitting tensile strength after 7 days of standard curing. All the cast cylinders had 4 in. in diameter and $8 \mathrm{in}$. in length and the total number of cast specimens was 66 . However, before the actual batching and testing started, a few preliminary mixes were batched and four specimens were cast and tested after three days of curing. These specimens were tested to see if they would yield reasonable results and to ensure that the research was valid and the continuation of any further research was feasible. Also, for self-compacting concrete, slump flow and U-type tests were carried out in order to evaluate the filling ability and the selfcompactability of the concrete.

In the second phase, small six samples with the dimensions of $70 \times 70 \times 12 \mathrm{~mm}$ have been cut from concrete specimens having $0.3,0.45$, and 0.6 water-cement ratios and analyzed under a normal stereo-zoom microscope, in order to compare the number of air voids in the normal and self-compacting concrete as shown in plate (1).

The materials used in the research were comprised of Portland cement type I, Water, River gravel, Natural sand, Mineral admixtures (fly ash- blast furnace slag- silica fume) and Chemical admixtures ( superplasticizer - viscosity modifying agent).

All the materials have been stored in the concrete laboratory in closed containers or bags to ensure that the conditions were kept constant throughout the research period. 


\section{Self-compacting Concrete Mix Design}

The self-compacting concrete mix design used in the study was based on previous works. All the mixes were prepared in $100 \mathrm{lbs}$ batches (for 6 specimens -4 by 8 inches cylinders and U-type test) using an electrical mixer. The mix proportions for casting the concrete specimens are given in Table (1). The type I Portland cement was replaced by blast furnace slag (25\%), fly ash (15\%), and silica fume (5\%). The water-cement ratios have been varied from 0.3 to 0.6 while the rest of the components were kept the same, except the chemical admixtures, which were adjusted for obtaining the selfcompactability of the concrete.

\section{Normal Concrete Mix Design}

Normal concrete mixes were prepared in $62 \mathrm{lbs}$ batches (for 6 specimens -4 by 8 inches cylinders) using the electrical mixer. The mix proportions for casting the concrete specimens are given in Table (2).

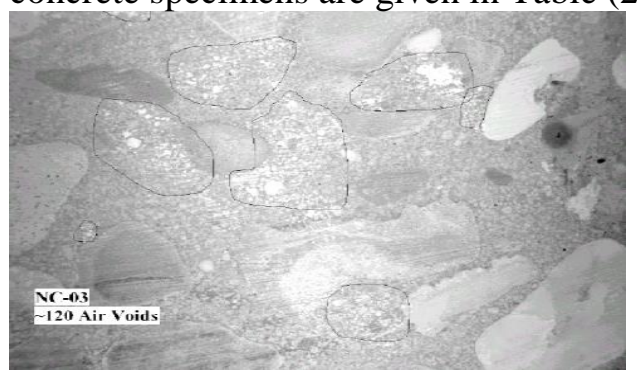

$\mathrm{NC}(\mathrm{W} / \mathrm{C}=\mathbf{0 . 3}$ and 120 air void $)$

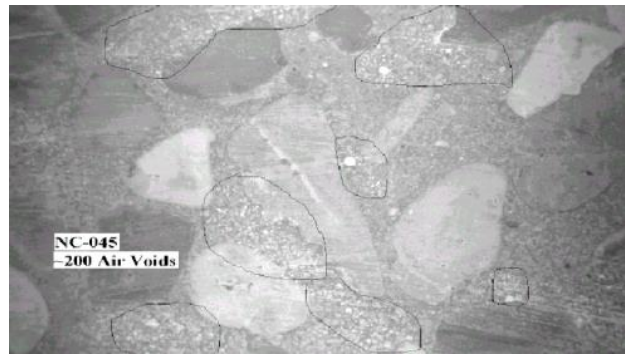

$\mathrm{NC}(\mathrm{W} / \mathrm{C}=0.45$ and 200 air void $)$

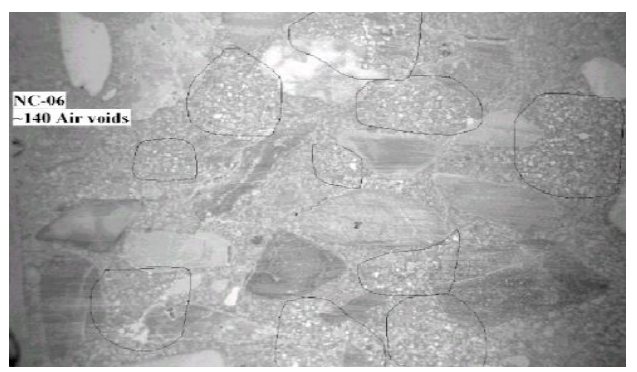

$\mathrm{NC}(\mathrm{W} / \mathrm{C}=\mathbf{0 . 6}$ and 140 air void $)$

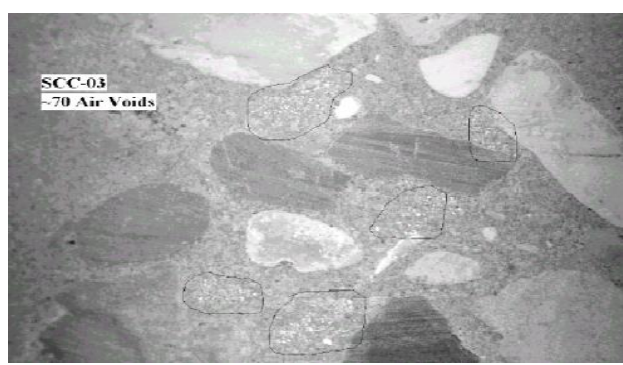

$\operatorname{SCC}(\mathrm{W} / \mathrm{C}=0.3$ and 70 air void $)$

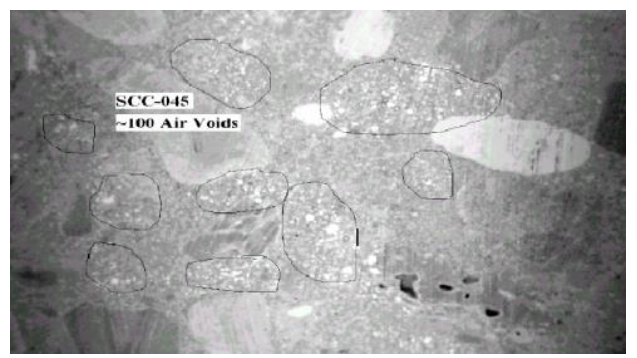

$\operatorname{SCC}(\mathrm{W} / \mathrm{C}=\mathbf{0 . 4 5}$ and 100 air void $)$

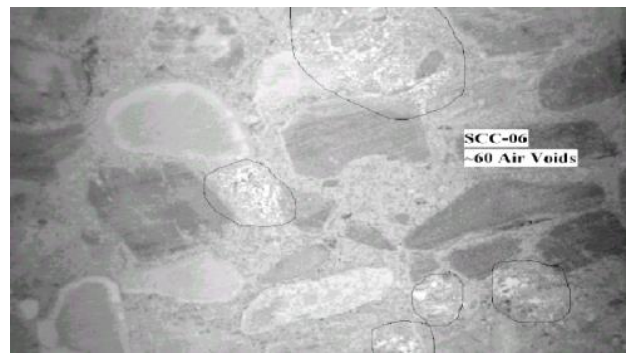

$\operatorname{SCC}(\mathrm{W} / \mathrm{C}=0.6$ and 60 air void $)$ 
Table (1) Self compacting concrete mix design.

\begin{tabular}{|l|c|c|c|c|c|}
\hline Water/Cement ratio & $\mathbf{0 . 3}$ & $\mathbf{0 . 4}$ & $\mathbf{0 . 4 5}$ & $\mathbf{0 . 5}$ & $\mathbf{0 . 6}$ \\
\hline Water (Ibs) & 6.6 & 8.8 & 9.9 & 11 & 13.2 \\
\hline Cement (Ibs) & 12.1 & 12.1 & 12.1 & 12.1 & 12.1 \\
\hline Slag Cement (Ibs) & 5.5 & 5.5 & 5.5 & 5.5 & 5.5 \\
\hline Fly Ash (Ibs) & 3.3 & 3.3 & 3.3 & 3.3 & 3.3 \\
\hline Silica Fume (Ibs) & 1.1 & 1.1 & 1.1 & 1.1 & 1.1 \\
\hline Fine Aggregate (Ibs) & 26 & 26 & 26 & 26 & 26 \\
\hline Coarse Aggregate (Ibs) & 46.4 & 46.4 & 46.4 & 46.4 & 46.4 \\
\hline HRWR (ml) & 340 & 100 & 80 & 50 & 20 \\
\hline VMA (ml) & 0 & 15 & 25 & 50 & 100 \\
\hline
\end{tabular}

Table (2)Normal concrete mix design.

\begin{tabular}{|l|c|c|c|c|c|}
\hline Water/Cement ratio & $\mathbf{0 . 3}$ & $\mathbf{0 . 4}$ & $\mathbf{0 . 4 5}$ & $\mathbf{0 . 5}$ & $\mathbf{0 . 6}$ \\
\hline Water (Ibs) & 4.1 & 5.5 & 6.2 & 6.8 & 8.2 \\
\hline Cement (Ibs) & 13.6 & 13.6 & 13.6 & 13.6 & 13.6 \\
\hline Fine Aggregate (Ibs) & 16.1 & 16.1 & 16.1 & 16.1 & 16.1 \\
\hline Coarse Aggregate (Ibs) & 28.2 & 28.2 & 28.2 & 28.2 & 28.2 \\
\hline
\end{tabular}

\section{RESULTS AND DISCUSSION}

\section{Slump Flow Test}

The consistency and workability of self-compacting concrete were evaluated using the slump flow test. Because of its ease of operation and portability, the slump flow test is the most widely used method for evaluating concrete consistency in the laboratory and at construction sites. In this study, the diameter of the concrete flowing out of the slump cone was obtained by calculating the average of two perpendicularly measured diameters for determining the above mentioned properties of concrete. The results from Table (3) show that the self-compacting concrete was complying with the requirements found in the literature. Thus, self-compacting concrete was assumed to having a good consistency and workability after gradually adjusting the chemical admixtures in the mix.

\section{U-type Test}

The U-type test was used to assess the self-compactability of concrete. The results presented in Table (4) show that the concrete can be considered self-compacting due to the fact that after opening the sliding gate SCC rose in the other half of the U-tube to a height greater than $85 \%$ of the maximum possible height, which is $340 \mathrm{~mm}$. 


\section{Concrete Density}

Densities of both types of concretes were determined by weighing the cylindrical specimens, after demolding them. The volume of a mold ( 8 " $\mathrm{x} 4$ ") is $0.00165 \mathrm{~m} 3$. The final densities for each type of concrete have been calculated by averaging the densities of all five water-cement ratios. Results regarding the densities and the weights for both types of concrete are presented in Table (5).

Table (3) Slump flow test result.

\begin{tabular}{|l|c|c|c|c|c|}
\hline Water/Cement ratio & $\mathbf{0 . 3}$ & $\mathbf{0 . 4}$ & $\mathbf{0 . 4 5}$ & $\mathbf{0 . 5}$ & $\mathbf{0 . 6}$ \\
\hline Spread Diameter $(\mathbf{m m})$ & 655 & 670 & 685 & 700 & 740 \\
\hline
\end{tabular}

Table (4) U-tube test result.

\begin{tabular}{|l|c|c|c|c|c|}
\hline Water/Cement ratio & $\mathbf{0 . 3}$ & $\mathbf{0 . 4}$ & $\mathbf{0 . 4 5}$ & $\mathbf{0 . 5}$ & $\mathbf{0 . 6}$ \\
\hline U-tube filling height $(\mathbf{m m})$ & 300 & 305 & 320 & 320 & 330 \\
\hline
\end{tabular}

Table (5) Normal and self compacting concrete densities.

\begin{tabular}{|l|c|c|c|c|c|}
\hline Water/Cement ratio & $\mathbf{0 . 3}$ & $\mathbf{0 . 4}$ & $\mathbf{0 . 4 5}$ & $\mathbf{0 . 5}$ & $\mathbf{0 . 6}$ \\
\hline NC*-Weights $(\mathbf{k g})$ & 3.91 & 3.88 & 3.86 & 3.85 & 3.83 \\
\hline SCC**-Weights $(\mathbf{k g})$ & 4.12 & 4.09 & 4.07 & 4.03 & 3.98 \\
\hline NC*-Density $\left(\mathbf{k g} / \mathbf{m}^{3}\right)$ & 2370 & 2352 & 2339 & 2333 & 2321 \\
\hline SCC*-Density $\left(\mathbf{k g} / \mathbf{m}^{\mathbf{3}}\right)$ & 2497 & 2479 & 2467 & 2442 & 2412 \\
\hline
\end{tabular}

* NC-Normal concrete, ** SCC-Self Compacting Concrete

\section{Splitting Tensile Strength}

Regarding the direct tensile strength, no relationship between the values of tensile strength from the splitting test and those measured in direct tension has been found yet. While it is commonly assumed that splitting tensile strength values are 5 to $12 \%$ higher than direct tensile strength values, this is not always true [8].

Due to the usage of mineral and chemical admixtures in the concrete mixtures an increase in the tensile strength of the self-compacting concrete could be observed, compared to the strength of conventional concrete.

Table (6) presents the splitting tensile strengths for normal and self-compacting concrete specimens, as they were tested after being cured for 28 days. In addition, Table (7) presents the splitting tensile strengths of both types of concrete after 7 days of curing. 
Table (6) Splitting tensile strength-28 days (ASTM C 496-96).

\begin{tabular}{|c|c|c|c|c|c|c|c|c|c|c|}
\hline \multirow{4}{*}{$\begin{array}{l}\text { W/C } \\
\text { Ratio }\end{array}$} & \multicolumn{10}{|c|}{ Type of Concrete } \\
\hline & \multicolumn{5}{|c|}{ Normal Concrete } & \multicolumn{5}{|c|}{ Self Compacting Concrete } \\
\hline & \multirow{2}{*}{$\begin{array}{l}\text { Max. } \\
\text { load } \\
\text { (KN) }\end{array}$} & \multicolumn{2}{|c|}{ Stress } & \multicolumn{2}{|c|}{$\begin{array}{c}\text { Average } \\
\text { stress }\end{array}$} & \multirow{2}{*}{$\begin{array}{l}\text { Max. } \\
\text { load } \\
\text { (KN) }\end{array}$} & \multicolumn{2}{|c|}{ Stress } & \multicolumn{2}{|c|}{$\begin{array}{c}\text { Average } \\
\text { stress }\end{array}$} \\
\hline & & $\mathrm{MPa}$ & PSI & $\mathrm{MPa}$ & PSI & & $\mathrm{MPa}$ & PSI & $\mathrm{MPa}$ & PSI \\
\hline \multirow{3}{*}{0.3} & 89.6 & 2.76 & 399.3 & \multirow{3}{*}{2.92} & \multirow{3}{*}{422.5} & 125.3 & 3.86 & 558.5 & \multirow{3}{*}{3.77} & \multirow{3}{*}{545} \\
\hline & 99.2 & 3.06 & 442.7 & & & 119.9 & 3.70 & 535.3 & & \\
\hline & 95.3 & 2.94 & 425.4 & & & 121.2 & 3.74 & 541.1 & & \\
\hline \multirow{3}{*}{0.4} & 91 & 2.81 & 406.6 & \multirow{3}{*}{2.60} & \multirow{3}{*}{376.7} & 105.6 & 3.26 & 471.7 & \multirow{3}{*}{3.37} & \multirow{3}{*}{488.1} \\
\hline & 78.9 & 2.43 & 351.6 & & & 112.2 & 3.46 & 500.6 & & \\
\hline & 83.3 & 2.57 & 371.8 & & & 110.1 & 3.40 & 491.9 & & \\
\hline \multirow{3}{*}{0.45} & 70.4 & 2.17 & 314 & \multirow{3}{*}{2.38} & \multirow{3}{*}{343.8} & 96.1 & 2.96 & 428.3 & \multirow{3}{*}{3.08} & \multirow{3}{*}{446.1} \\
\hline & 78.7 & 2.43 & 351.6 & & & 95 & 2.93 & 423.9 & & \\
\hline & 82.1 & 2.53 & 366 & & & 108.9 & 3.36 & 486.1 & & \\
\hline \multirow{3}{*}{0.5} & 71.2 & 2.2 & 318.3 & \multirow{3}{*}{2.07} & \multirow{3}{*}{299} & 89.2 & 2.75 & 397.9 & \multirow{3}{*}{2.76} & \multirow{3}{*}{399.8} \\
\hline & 63.8 & 1.97 & 285 & & & 88.3 & 2.72 & 393.5 & & \\
\hline & 65.9 & 2.03 & 293.7 & & & 91.5 & 2.82 & 408 & & \\
\hline \multirow{3}{*}{0.6} & 60.1 & 1.85 & 267.7 & \multirow{3}{*}{1.76} & \multirow{3}{*}{255.1} & 76.1 & 2.35 & 340 & \multirow{3}{*}{2.35} & \\
\hline & 57.4 & 1.77 & 256.1 & & & 73.7 & 2.27 & 328.4 & & 340 \\
\hline & 54.3 & 1.67 & 241.6 & & & 78.8 & 2.43 & 351.6 & & \\
\hline
\end{tabular}

Table (7) Splitting tensile strength -7 days.

\begin{tabular}{|c|c|c|c|c|c|c|c|c|c|c|}
\hline \multirow{4}{*}{$\begin{array}{l}\text { W/C } \\
\text { Ratio }\end{array}$} & \multicolumn{10}{|c|}{ Type of Concrete } \\
\hline & \multicolumn{5}{|c|}{ Normal Concrete } & \multicolumn{5}{|c|}{ Self Compacting Concrete } \\
\hline & \multirow{2}{*}{$\begin{array}{l}\text { Max. } \\
\text { load } \\
(\mathrm{KN})\end{array}$} & \multicolumn{2}{|c|}{ Stress } & \multicolumn{2}{|c|}{$\begin{array}{c}\text { Average } \\
\text { stress }\end{array}$} & \multirow{2}{*}{$\begin{array}{l}\text { Max. } \\
\text { load } \\
(\mathrm{KN})\end{array}$} & \multicolumn{2}{|c|}{ Stress } & \multicolumn{2}{|c|}{$\begin{array}{c}\text { Average } \\
\text { stress }\end{array}$} \\
\hline & & $\mathrm{MPa}$ & PSI & $\mathrm{MPa}$ & PSI & & $\mathrm{MPa}$ & PSI & $\mathrm{MPa}$ & PSI \\
\hline \multirow{3}{*}{0.4} & 74.9 & 2.31 & 334.2 & \multirow{3}{*}{2.32} & \multirow{3}{*}{336} & 94.7 & 2.92 & 422.5 & \multirow{3}{*}{3.07} & \multirow{3}{*}{445.1} \\
\hline & 78.5 & 242 & 350 & & & 108.4 & 3.34 & 483.2 & & \\
\hline & 72.6 & 2.24 & 324 & & & 96.2 & 2.97 & 429.7 & & \\
\hline
\end{tabular}

It can be seen from Figure (1) that the strengths of SCC after 7 days are comparable to those obtained after 28 days for NC. This was possible because of the use of silica fume and fly ash, which usually tend to increase the early strength of concrete.

The graph also shows that a decrease in the tensile strength takes place as the water cement ratio is increased. This shows that, regarding the water-cement ratio, the selfcompacting concrete behaves like conventional concrete. The values used in the graph were the average values (out of three tests) obtained for each water-cement ratio. The 
average values of splitting tensile strengths (out of three tests) for each water-cement ratio are shown in Figure (2).

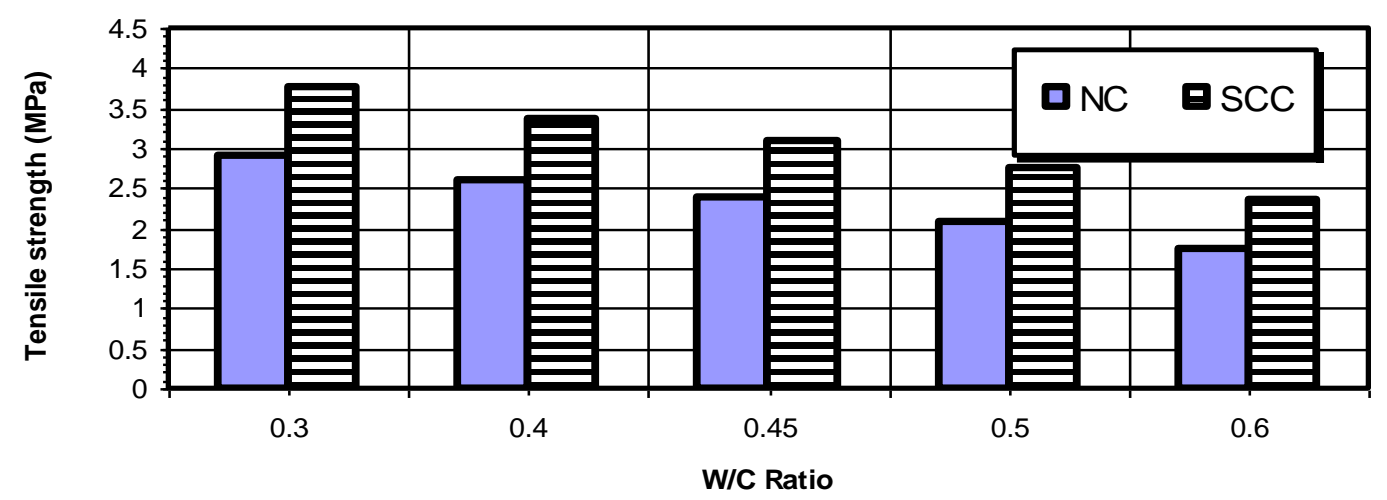

Fig. (1) Variation of compressive strength with W/ C ratio.

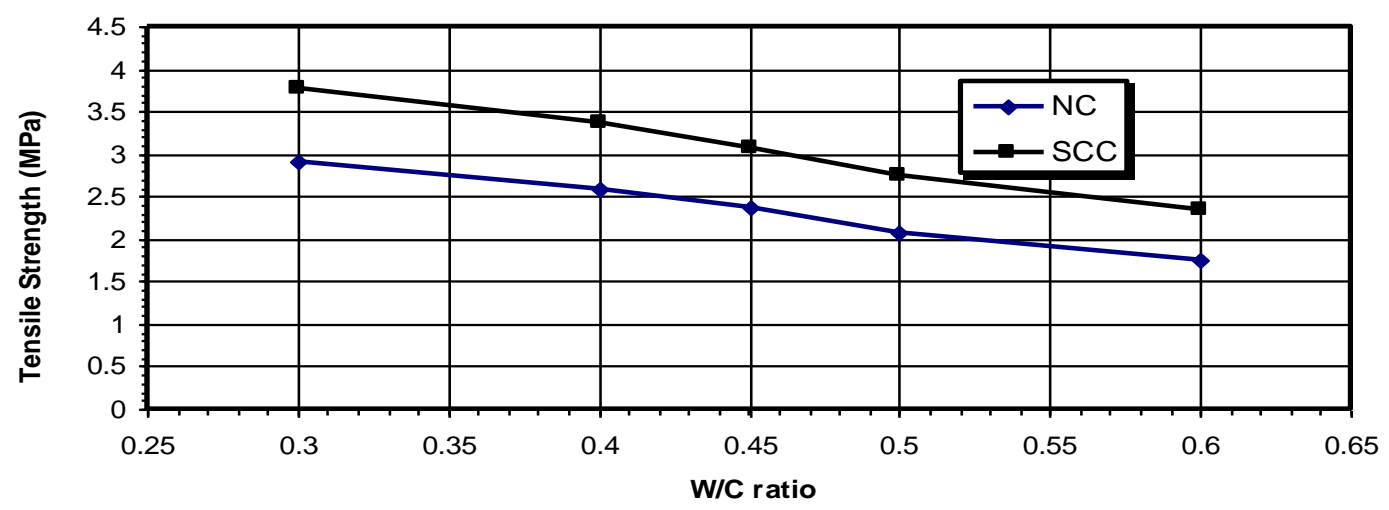

Fig. (2) Variation of compressive strength with W/ C ratio.

Regardless of the water content and the type of concrete, all specimens have had a linear type of fracture and the same relief (surface shape) on the fractured faces as shown in Plate (2). It can be inferred that even if the tensile strength of self-compacting concrete was greater than that of normal concrete (approx. 30\%), this did not influence the type of fracture of cylindrical concrete specimens. Also, the proportions of coarse aggregate fractured during tests were different. Taking into account that each fractured face of the cylindrical specimens contained around 60 coarse aggregate particles, the percentage of fractured aggregate for SCC was 15-25\% (9-15 aggregate particles), while for normal concrete was around 10\% (4-6 aggregate particles), which meant that a better bonding between aggregate and cement paste existed in SCC compared to normal concrete as indicated in Table (8) and Plate (3). The percentages were obtained by averaging the number of fractured aggregate particles from three specimens. No segregation has been observed in SCC specimens after testing them. 


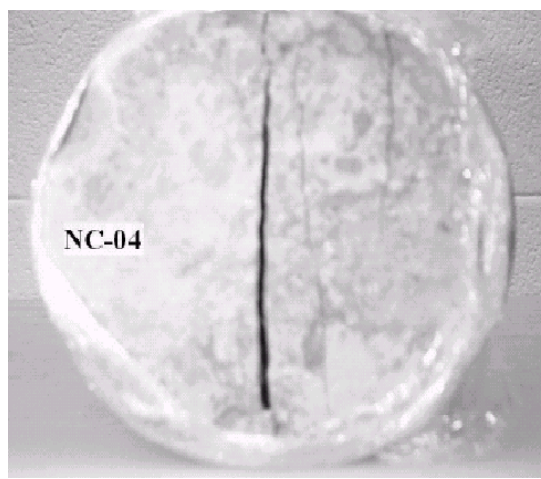

$\mathrm{NC}-0.4$

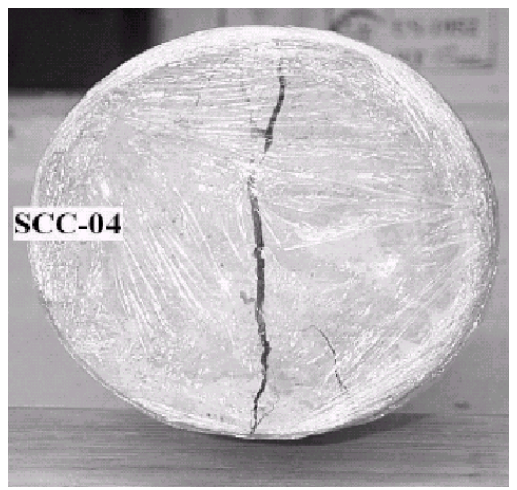

SCC-0.4

Plate (2) Linear fracture of cylinders

Table (8) Aggregate fracture percentages in normal and self compacting concretes.

\begin{tabular}{|c|c|c|c|c|}
\hline \multirow{2}{*}{ W/C Ratio } & \multicolumn{2}{|c|}{ Normal Concrete } & \multicolumn{2}{c|}{ Self compacting concrete } \\
\cline { 2 - 5 } & $\begin{array}{c}\text { No. of } \\
\text { fractured } \\
\text { agg. particles }\end{array}$ & $\begin{array}{c}\text { Fractured } \\
\text { agg. (\%) }\end{array}$ & $\begin{array}{c}\text { No. of } \\
\text { fractured } \\
\text { agg. particles }\end{array}$ & $\begin{array}{c}\text { Fractured agg. } \\
(\boldsymbol{\%})\end{array}$ \\
\hline 0.3 & 15 & 25 & 6 & 10 \\
\hline 0.4 & 12 & 20 & 5 & 8.3 \\
\hline 0.45 & 11 & 18 & 5 & 8.3 \\
\hline 0.5 & 10 & 16.7 & 4 & 6.7 \\
\hline 0.6 & 9 & 15 & 4 & 6.7 \\
\hline
\end{tabular}

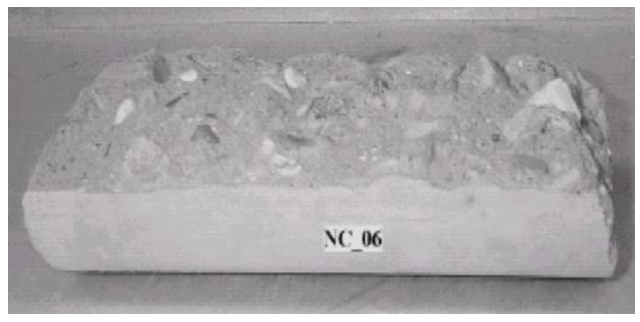

NC-0.6

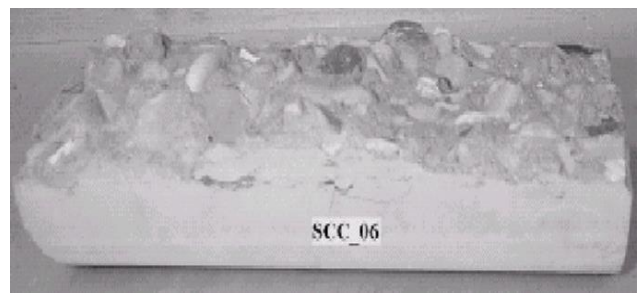

SCC-0.6

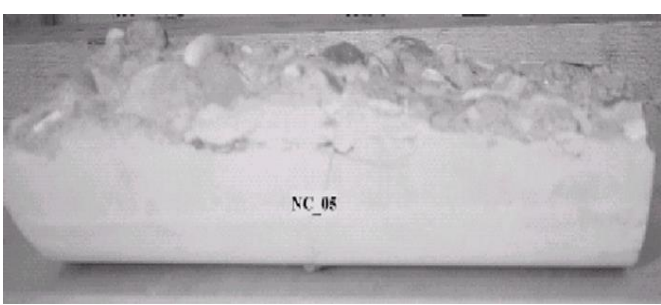

NC-0.5

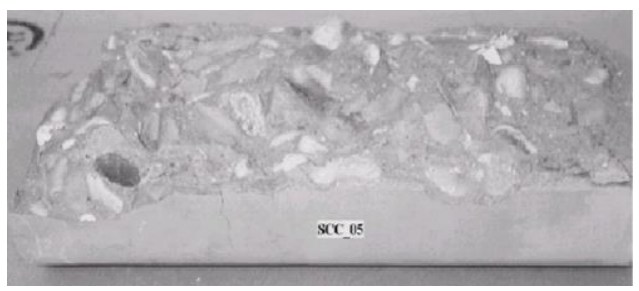

SCC-0.5

Plate (3) concrete surface shape of fracture face $(w / c=0.5$ and 0.6$)$. 


\section{Compressive Strength}

Self-compacting concrete has also shown an increase in compressive strength, with an average of 65 percent. The values used for plotting the graph in Figure (3) were the average values (out of three tests) obtained for each water-cement ratio. The average values of compressive strengths (out of three tests) for each water-cement ratio are shown in Figure (4) and Table (9).

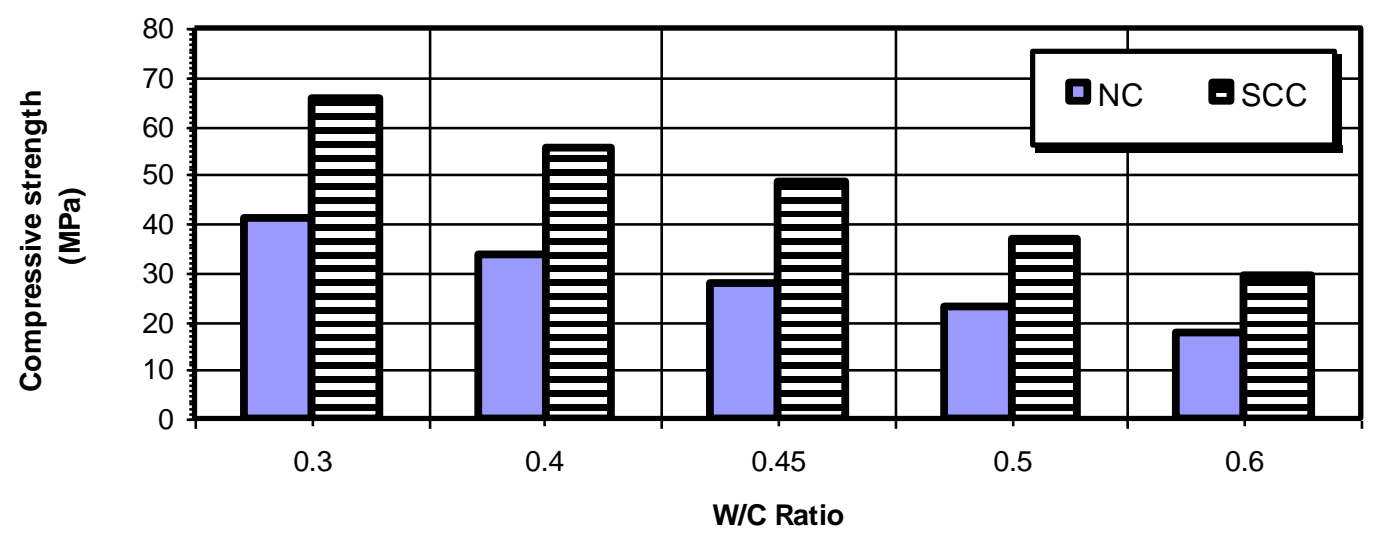

Fig. (3) Variation of compressive strength with W/ C ratio.

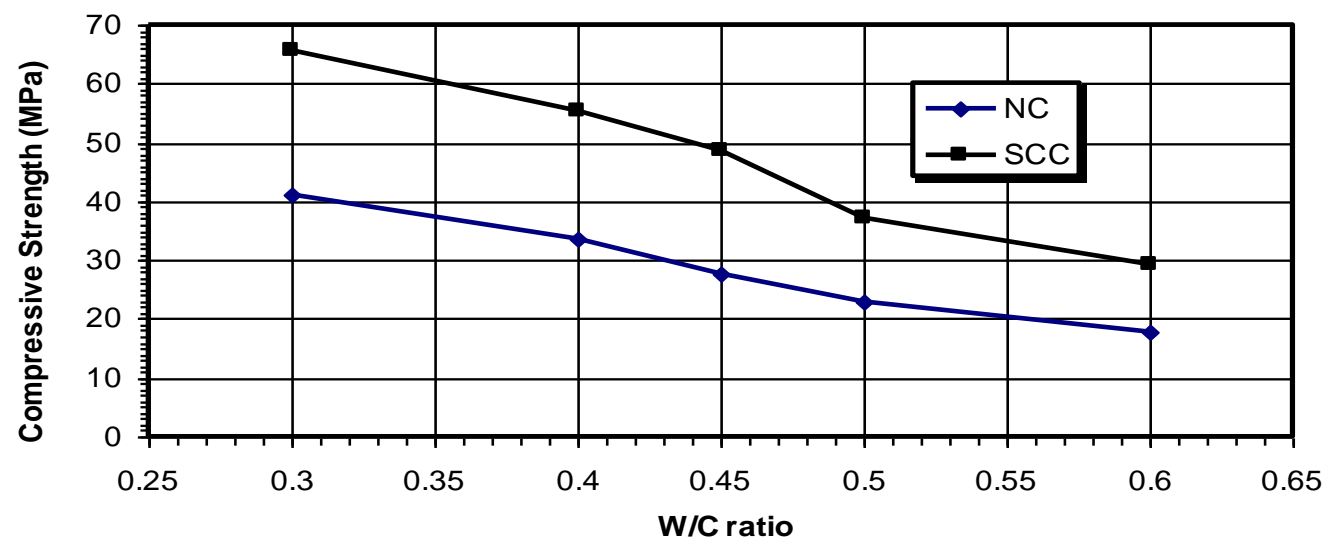

Fig. (4) Variation of compressive strength with W/ C ratio. 
BEHAVIOR AND BONDING CHARACTERISTICS....

Table (9) Compressive strength - 28 days (ASTM C 39-94).

\begin{tabular}{|c|c|c|c|c|c|c|c|c|c|c|}
\hline \multirow{4}{*}{$\begin{array}{l}\text { W/C } \\
\text { Ratio }\end{array}$} & \multicolumn{10}{|c|}{ Type of Concrete } \\
\hline & \multicolumn{5}{|c|}{ Normal Concrete } & \multicolumn{5}{|c|}{ Self Compacting Concrete } \\
\hline & \multirow{2}{*}{$\begin{array}{l}\text { Max. } \\
\text { load } \\
(\mathrm{KN})\end{array}$} & \multicolumn{2}{|c|}{ Stress } & \multicolumn{2}{|c|}{ Average stress } & \multirow{2}{*}{$\begin{array}{l}\text { Max. } \\
\text { load } \\
(\mathrm{KN})\end{array}$} & \multicolumn{2}{|c|}{ Stress } & \multicolumn{2}{|c|}{ Average stress } \\
\hline & & $\mathrm{MPa}$ & PSI & $\mathrm{MPa}$ & PSI & & $\mathrm{MPa}$ & PSI & $\mathrm{MPa}$ & PSI \\
\hline \multirow{3}{*}{0.3} & 330.3 & 40.74 & 5894.6 & \multirow{3}{*}{40.94} & \multirow{3}{*}{5923.9} & 546.2 & 67.37 & 9747.4 & \multirow{3}{*}{65.76} & \multirow{3}{*}{9514} \\
\hline & 330.9 & 40.82 & 5906 & & & 525.7 & 64.84 & 9381.3 & & \\
\hline & 334.6 & 41.27 & 5971.1 & & & 527.5 & 65.06 & 9413.2 & & \\
\hline \multirow{3}{*}{0.4} & 270.8 & 33.40 & 4832.5 & \multirow{3}{*}{33.43} & \multirow{3}{*}{4837.3} & 466.2 & 57.51 & 8320.8 & \multirow{3}{*}{55.45} & \multirow{3}{*}{8023.2} \\
\hline & 266.2 & 32.84 & 4751.4 & & & 451.4 & 55.68 & 8056 & & \\
\hline & 276.1 & 34.06 & 4928 & & & 431.1 & 53.17 & 7692.8 & & \\
\hline \multirow{3}{*}{0.45} & 228.2 & 28.15 & 4072.9 & \multirow{3}{*}{27.61} & \multirow{3}{*}{3995.2} & 387.3 & 47.77 & 6911.6 & \multirow{3}{*}{48.46} & \multirow{3}{*}{7012} \\
\hline & 219.9 & 27.12 & 3923.8 & & & 397.4 & 49.02 & 7092.4 & & \\
\hline & 223.5 & 27.57 & 3988.9 & & & 394 & 48.6 & 7031.7 & & \\
\hline \multirow{3}{*}{0.5} & 184.7 & 22.78 & 3295.9 & \multirow{3}{*}{23.13} & \multirow{3}{*}{3346.1} & 292.9 & 36.13 & 5227.4 & \multirow{3}{*}{36.98} & \multirow{3}{*}{5350} \\
\hline & 190.6 & 23.51 & 3401.5 & & & 291.2 & 35.92 & 5197.1 & & \\
\hline & 187.2 & 23.09 & 3340.8 & & & 315.2 & 38.88 & 2625.3 & & \\
\hline \multirow{3}{*}{0.6} & 151 & 18.75 & 2712.8 & \multirow{3}{*}{17.68} & \multirow{3}{*}{2557.9} & 238.7 & 29.44 & 4259.5 & \multirow{3}{*}{29.08} & \\
\hline & 147.9 & 18.24 & 2639 & & & 226.4 & 27.93 & 4041 & & 4207 \\
\hline & 130.1 & 16.05 & 2321.9 & & & 242.1 & 29.86 & 4320.3 & & \\
\hline
\end{tabular}

It can be said that due to the strengths over $50 \mathrm{MPa}$ obtained for 0.3 and 0.4 water cement ratios, self-compacting concrete can be considered a high-strength concrete, capable of replacing conventional concrete in the construction field. Regarding the type of fracture, both types of concrete specimens have showed similar patterns, the commonest one being the columnar type due to the rubber caps used during testing. Some pictures of compressive strength types of fracture are presented in Plate (4). No segregation has been observed in SCC specimens after testing them. 


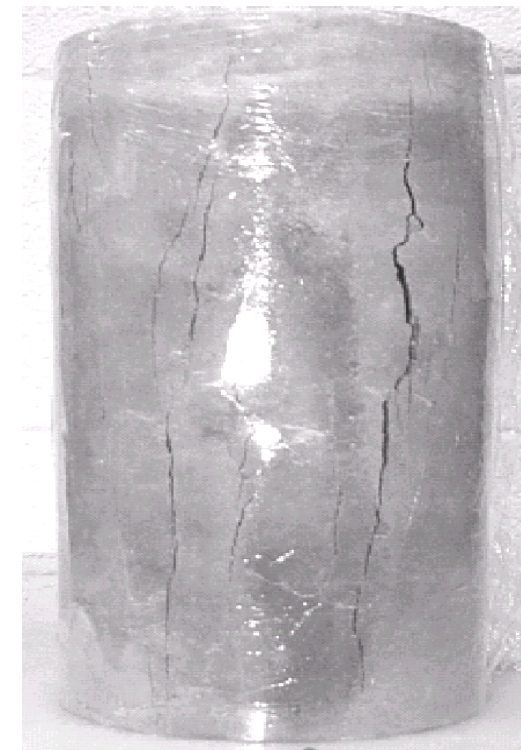

Columnar failure

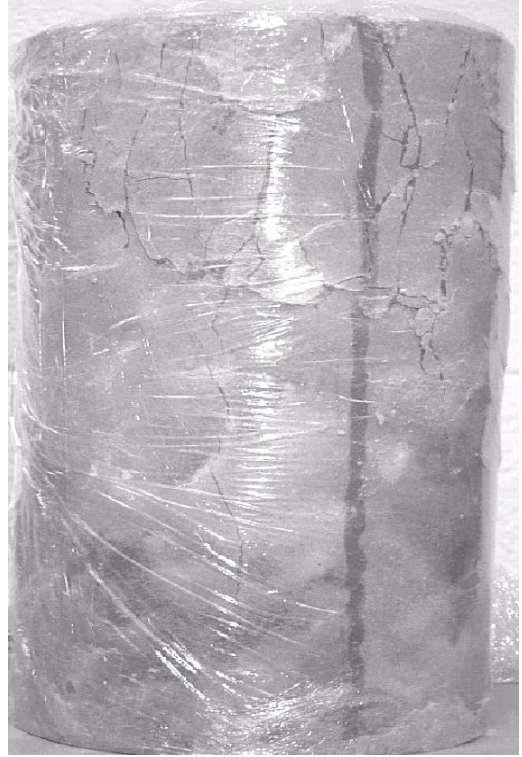

Cone and split failure

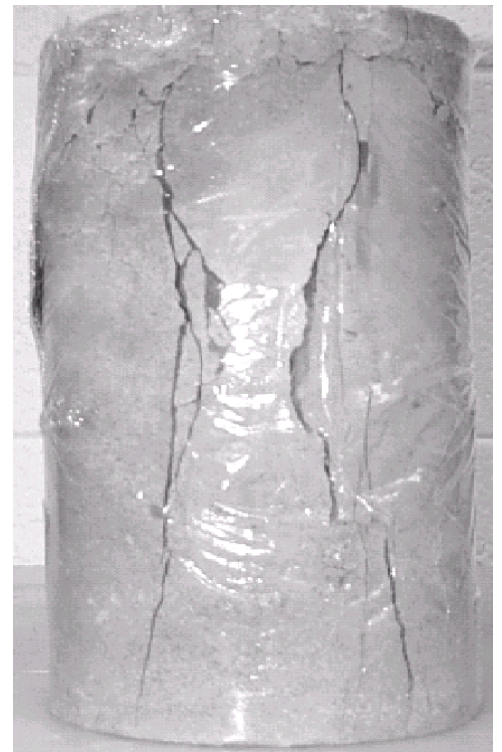

Cone failure

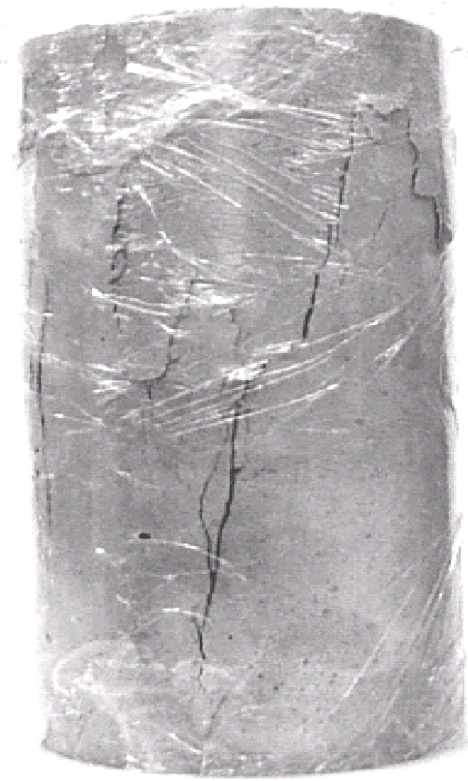

Shear failure

Plate (4) compressive strength test-type of fracture.

\section{Relationship between Tensile and Compressive Strengths of SCC}

The variation of splitting and compressive strengths is shown in Figure (5). For this study, the values of the ratios for both types of concretes were between 0.06 and 0.10 , 
so they fell within the usual values of the ratio between splitting and compressive strength, in the interval between 0.06 and 0.20 .

In order to estimate better the relationship between the two variables the regression analysis has been used based on the existing data, using Microsoft Excel. The trend lines are similar to those given by different aggregates in Figure (6).

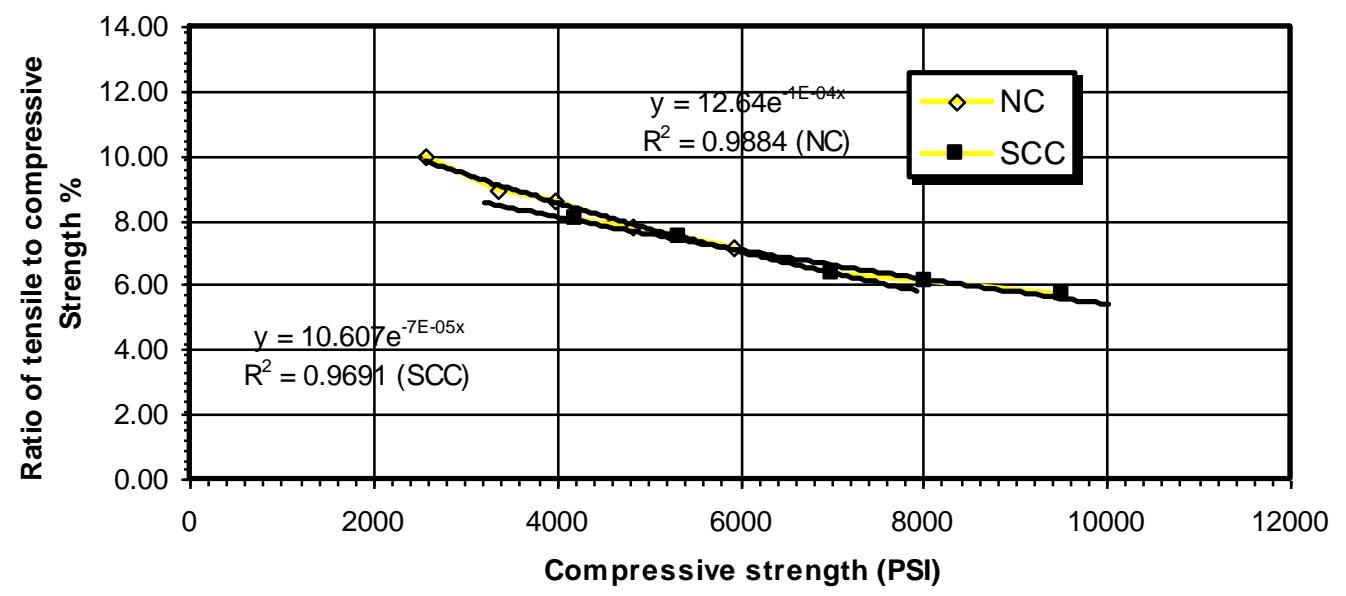

Fig. (5) Splitting tensile strength versus compressive strength.

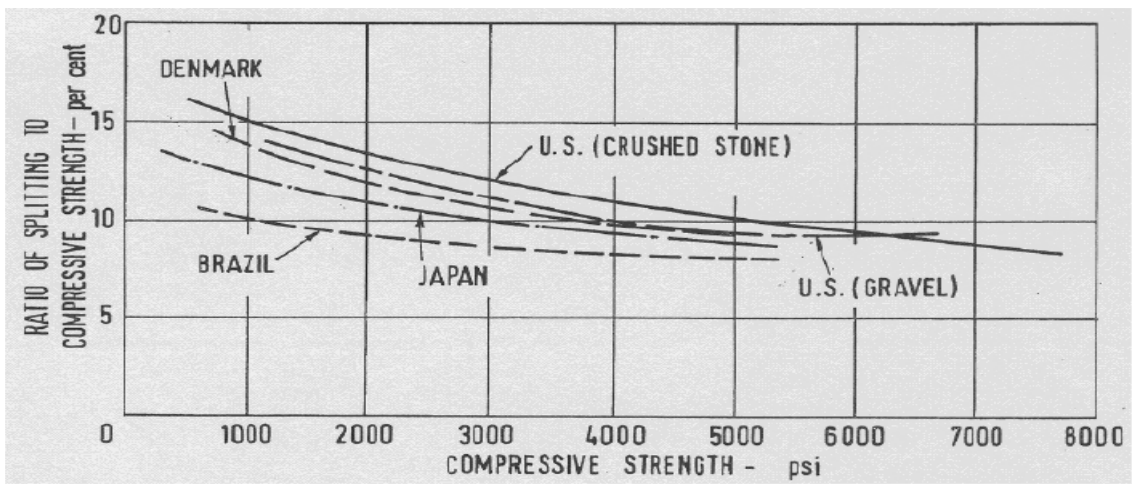

Fig. (6) Splitting tensile strength of cylinders of different compressive strength [9].

\section{Bonding between Coarse Aggregate and Cement Paste}

In the last few decades, a lot of research has been done regarding the improvement of the concrete performance. As a result of this paper, concretes of higher strength and better durability are being manufactured and used. In order to achieve these types of concretes, their performance parameters can be altered for the better by choosing proper materials or by modifying the physical interfaces between the materials. A better bonding due to the smaller physical interfaces in SCC increased the percentages of fractured aggregate compared to normal concrete. Intervals of the physical interfaces 
widths from all the images acquired are presented in plate (5) and Table (10). Five measurements have been carried out for each water/cement ratio.

Table (10) Interfaces microcracks width intervals for normal and self compacting concretes.

\begin{tabular}{|c|c|c|}
\hline W/C Ratio & Normal Concrete & Self compacting concrete \\
\hline 0.3 & $0.62-1.28-1.56-1.64-1.75$ & $0.01-0.5-0.51-0.62-0.75$ \\
\hline 0.4 & $0.63-2.25-2.75-3.21-3.22$ & $0.01-0.10-0.12-0.2-1.12$ \\
\hline 0.6 & $1.23-1.75-2.25-3.12-3.38$ & $0.01-0.05-0.31-0.37-0.60$ \\
\hline
\end{tabular}

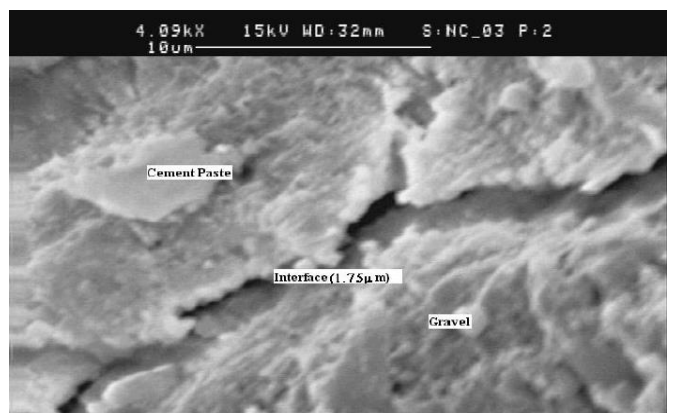

$\mathrm{NC}(\mathrm{w} / \mathrm{c}=\mathbf{0 . 3})$

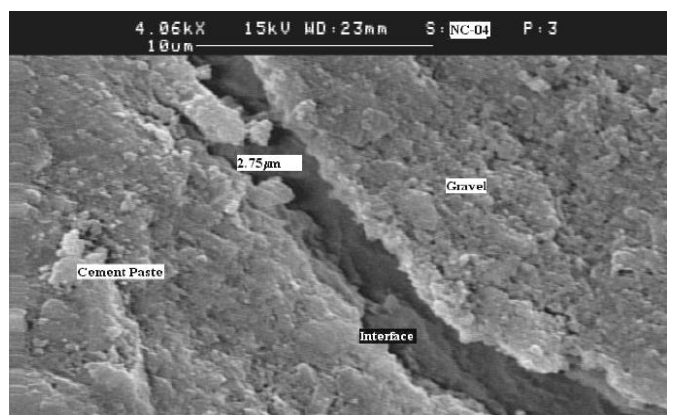

$\mathrm{NC}(\mathrm{w} / \mathrm{c}=\mathbf{0 . 4})$

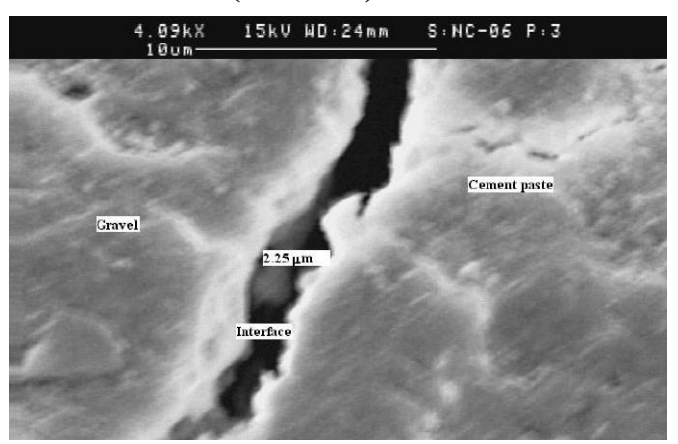

$\mathrm{NC}(\mathrm{w} / \mathrm{c}=\mathbf{0 . 6})$

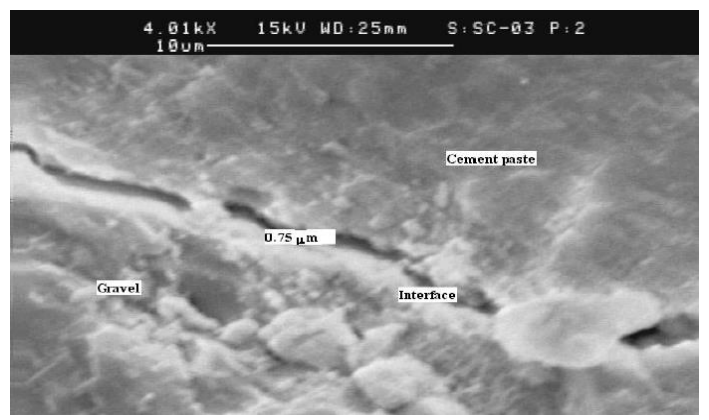

$\operatorname{SCC}(\mathbf{w} / \mathbf{c}=0.3)$

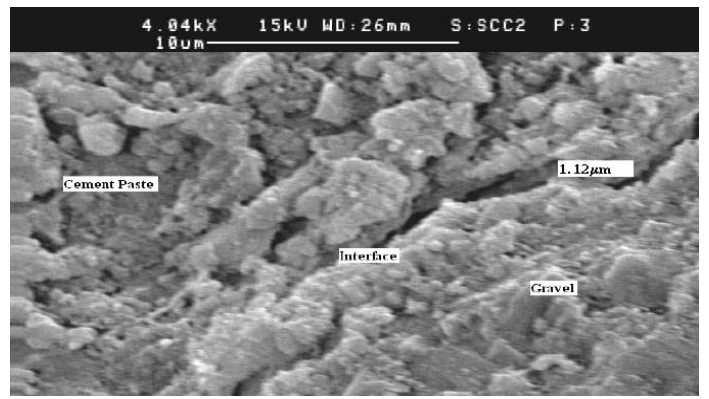

$\operatorname{SCC}(\mathbf{w} / \mathbf{c}=0.4)$

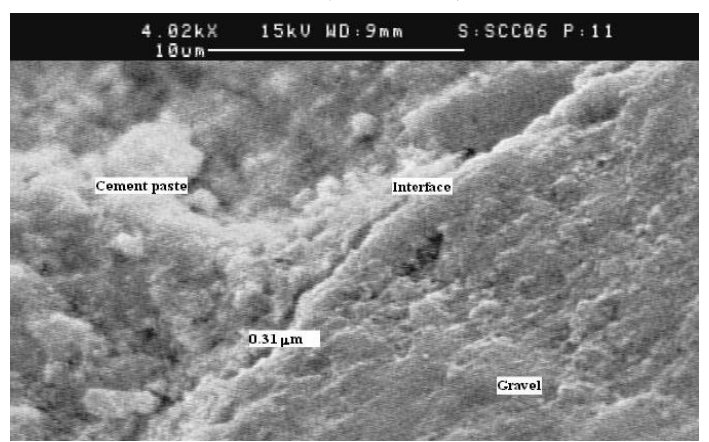

$\operatorname{SCC}(\mathbf{w} / \mathbf{c}=0.6)$

Plate (5) Scanning electronic microscope images. 


\section{CONCLUSIONS AND RECOMMENDATIONS}

Taking into account the findings from this study, previously presented, the following conclusions can be drawn:

(1) It has been verified, by using the slump flow and U-tube tests, that selfcompacting concrete (SCC) achieved consistency and self-compactability under its own weight, without any external vibration or compaction. Also, because of the special admixtures used, SCC has achieved a density between 2400 and $2500 \mathrm{~kg} / \mathrm{m} 3$, which was greater than that of normal concrete, $2370-2321 \mathrm{~kg} / \mathrm{m} 3$. (2) Self-compacting concrete can be obtained in such a way, by adding chemical and mineral admixtures, so that its splitting tensile and compressive strengths are higher than those of normal vibrated concrete. An average increase in compressive strength of $60 \%$ has been obtained for SCC, whereas $30 \%$ was the increase in splitting tensile strength.

(3) Self-compacting concrete has shown smaller interface microcracks than normal concrete, fact which led to a better bonding between aggregate and cement paste and to an increase in splitting tensile and compressive strengths. A measure of the better bonding was the greater percentage of the fractured aggregate in SCC (20-25\%) compared to the $10 \%$ for normal concrete.

(4) Self-compacting concrete has two main advantages. One, relates to the construction time, which in most of the cases is shorter than the time when normal concrete is used, due to the fact that no time is wasted with the compaction through vibration. The second advantage is related to the placing.

(5) As long as SCC does not require compaction, it can be considered environmentally friendly, because if no vibration is applied no noise is made.

(6) Test methods have to be capable of a rapid and reliable assessment of key properties of fresh SCC on a construction site. At the same time, the testing equipment should be reliable, easily portable and inexpensive. The test procedure should be carried out by a single operator and the test results have to be interpreted with a minimum of training. One primary application of these test methods would be in verification of compliance on sites and in concrete production plants, if self compacting concrete could be manufactured in large quantities.

\section{REFERENCES}

[1] Heniegal, A. M., and Fahmy, W. S. " Properties and Bond Behavior of Self Compacting Concrete (SCC)", Mansoura Engineering Journal, V. 13, No. 1, March 2006.

[2] Bartos, J. M., "M easurement of Key Properties of Fresh Self-compacting Concrete", CEN/PNR Workshop, Paris (2000). 
[3] Okamura, H, "Self-Compacting High-Performance Concrete", Concrete International, pp.50-54(1997).

[4] Ozawa, K., "Development of high performance concrete based on the durability design of concrete structures", EASEC-2, Vol. 1, pp.445-450 (1989).

[5] Okamura, H, "Self-Compacting High-Performance Concrete", Concrete International, pp.50-54 (1997).

[6]Maekawa, K., and Ozawa, K. "Development of SCCs Prototype", Self Compacting High Performance Concrete, Social System Institute,pp. 20-30(1999).

[7] Dehn, F., K. Holschemacher, and D. Weisse, "Self-Compacting Concrete Time Development of the Material Properties and the Bond Behavior", LACER No. 5, pp.115-123 (2000).

[8] Mindess, S., J. F. Young, and D. Darwin, "Concrete", Second Edition, Prentice Hall (2003).

[9] Neville, A. M., "Properties of concrete", Third Edition, Longman Scientific \& Technical, UK (1993).

\section{سلوك و طبيعة تماسك الخرسانة ذاتية الدمك أشعف محمد حنيجل - ولبي صفوت السبيا}

الخرسانة ذاتية الدمك لها القدرة على السريان و الدمك و ملأ الفرم تماما وذلك تحت تأثير وزنهـا دون أى هـزأو دمـك ممـا يسـمح لهـا بمــأ الفراغـات لأى مقـاس أو شـكل للفـرم الخرسانية دون حدوث إنفصال حبيبى أو نزف. و لذا يتم إستخلال هذه الخواص الإيجابية عند الصب فى الظروف الصعبة مثل إستخدام شبكة حديد تشليح كثيفة أو فرم ضيقة و ذات أثنكال خاصـة.ويهدف هذا البحث إلى دراسـة سلوك الخرسـانة ذاتيـة الدمك بمقارنـة نتائج إجهاداتها فى حالة الثـد الغير مباشر وكذلك الضـط مـع نتائج الخرسـانة العاديـة المتداولة.

فى هذا البحث تم إعداد 66 عينة اسطوانية مقاس (10سم × 20سم) منها 60 عينة لعمل إختبارات الثد الغير مباشر و الضغط بعد 28 يوما من المعالحة القياسية بالإضافة إلى 6 إسطوانات لعمل إختبارات مبدئية عل الثد قبل البدأ فى البرنامج البحثى و ذلك لدراسة مـا إذا كانت الخرسانة ذاتيـة الدمك تعطى نتائج أفضل فى حالتى الثد و الضغط. وقد كانت نسب الماء إلى الأسمنت المستخدمة فى الخلطات (0.3-0.4-0.45-0.5- 
مع ملاحظة ثبات باقى نسب الخلطة العادية فى الخرسانة ذاتية الدمك باستثناء إستخدام الإضافات اللازمة لعمل خرسانة ذاتية الدمك. وقدأظهرت النتائج أن الخرسانة ذاتية الدمك لك لهك

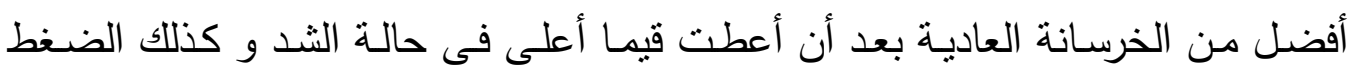

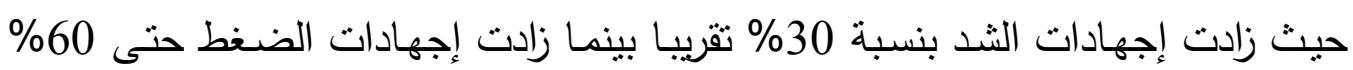

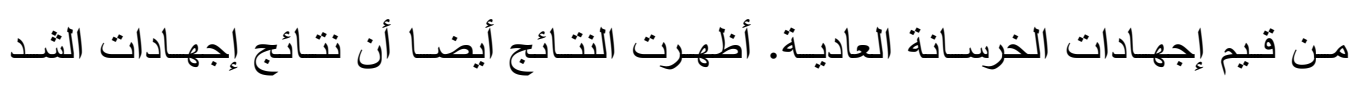
للخرسانة ذاتيـة الدمك بعد 7 أيام زادت عن مثيلاتها فى الخرسانة العادية بعد 28 يوما مما كان مؤشرا متوقعا فى ظل نواجد المواد الإضـافية و التى تزيد من ترابط الركام مـع عجينة الأسمنت و من ثم زيادة الإجهادات. و على الجانب الأخر، فقد تم دراسـة تماسك عجينة الأسمنت مـع الركام لكل نوع من الأن الخرسانة و ذلك بتجهيز عينات صغيرة من الخرسانة (قطر 25مم تقريبا و سمك 4مم) و ذلك لتحليلها تحت الميكروسكوب الاككترونى بالإضـافة إلى 6 عينات خرسـانية صغيرة

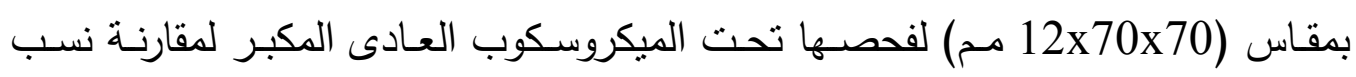
الفراغات الهوائية لكل نوع من الخرسانة. وقد أظهرت نتائج الفحص الميكروسكوبى تحسنا ملحوظا للخرسانة ذاتية الدمك حيث زادت نسبة الترابط بين عجينـة الأسمنت و الركام و

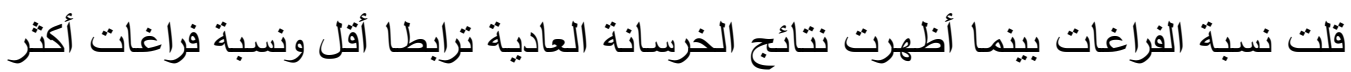
مما يؤكد دعم نتائج الإجهادات و تحسنها الملحوظ بالنسبة للخرسانة ذاتية الدمك. 